broker shall be on the party behind the outside broker and not on the exchange broker. Applied this way, the custom is reasonable.

Its reasonableness is far from apparent, however, when after the stock has been paid for the custom is relied upon to justify set-off on a subsequent debt. This, it will be remembered, was the situation in the Lynch case. The exchange broker would deliver the stock upon payment. But delivery of the stock is not requested; it remains in the account. The outside broker requests an extension of credit. The stock in the account will probably be a basis for giving the credit ${ }^{25}$ and it will serve as security. However, the exchange broker knows that the outside broker more times than not is acting for a principal. It does not seem unreasonable that he should inquire into the ownership of any stock in the account which is already paid for. He is now taking a risk by extending credit in the form of a loan; if he wishes protection against undisclosed principals he should inquire into the ownership behind any stock he plans to hold as security for the loan.

To hold that the custom destroys the neecssity for such inquiry, and that the custom can be used as a means of protecting the exchange broker in such a situation, is to give the custom unreasonable effect. Such doctrine encourages exchange brokers to extend credit to outside brokers on security they have reason to believe belongs to someone else. The Utah Supreme Court has given too broad an application to the custom. It has allowed a custom which has as its purpose protection of brokers in margin transactions to aid "a broker in financing a private transaction with the assets of the customers of the Stock Exchange." ${ }^{26}$ Applied this way, the custom is unreasonable.

${ }^{5}$ The dissent in the Lynch case points out that Hogle was either relying on the stock in the account, or on Badger personally, when the advancement was made.

${ }^{20}$ Dissenting opinion, Lynch v. Maw, 3 Utah 2d 271, 277, 282 P. 2d 842, 845 (1955).

\title{
SPECIFICATION AND APPORTIONMENT CONTRACTS: COMMON LAW AND UNIFORM COMMERCIAL CODE
}

Commercial transactions often require a degree of flexibility which is best achieved by leaving open for subsequent determination certain terms of the agreement. A familiar open term arrangement is found in the specifications and apportionment agreement. Typically, in such an agreement the total quantity of merchandise to be purchased is stated, ${ }^{1}$ the buyer having power to specify certain stated sizes, styles, or qualities which vary from a base price according to a list of differentials.

${ }^{1}$ Occasionally the quantity is measured in dollars, as, for example, in Bowen v. Virginia Lee Candies, 44 S.W. 2d 502 (Tex. Civ. App., 1931), wherein the buyer had promised to purchase to the extent of $\$ 60$ per month. 
The usual apportionment agreement lends itself to three basic alternative analyses. The first, viewing the power of selection as non-obligatory, results in a finding that the agreement is too indefinite to be enforced. This view finds support in the difficulty of determining an appropriate measure of damages. A second alternative would be to put the buyer under a duty to exercise his power, the performance of which is a condition precedent to the seller's duty to perform. Under this analysis the buyer's failure to specify would give rise to a cause of action in the seller. A third and less obvious construction of the agreement, also treating the power of selection as obligatory, would allow the seller to exercise a power of selection as an alternative to holding the buyer for breach when the latter fails to specify. ${ }^{2}$

No court has dissented from the proposition that once the specification has been made, any uncertainty in the agreement is removed. ${ }^{3}$ But where the power of selection has not been exercised, some courts, adopting the first analysis, have been unable to find an enforceable contract. This inability is caused by an alleged uncertainty in the agreement. The uncertainty is said to be fatal not because it renders the court unable to determine whether the parties intended to be contractually bound ${ }^{4}$ but because there was no consensus ad idem, the proof of this lying in the inability of the court to find an appropriate measures of damages. On the other hand, among those courts which have been able to uphold the contract there has been some difference of opinion as to what consitutes an adequate basis of relief for the aggrieved party. It is the purpose of this comment critically to examine and compare the treatment of these agreements under the common law and under the proposed Uniform Commercial Code, viewing the questions of the validity of the agreements and the appropriate measure of damages for their breach.

\section{I}

Typical of the cases in which the first analysis has been adopted is Wheeling Steel \& Iron Co. v. Evans, ${ }^{5}$ an action by a seller against the president of a buyer company for breach of his alleged warranty of authority. The case

${ }^{2}$ This is the position adopted in the Uniform Commercial Code, section 2-311. (All Code references are to the Official Draft, 1952.) A fourth analysis would treat the buyer's power of selection as merely a privilege, his failure to exercise it not excusing the seller from his duty to deliver. In the absence of specifications by the buyer, the seller would thus be under a duty to select an apportionment. This analysis is discussed infra, at note 12.

${ }^{3}$ Mebius \& Drescher Co. v. Mills, 150 Cal. 229, 88 Pac. 917 (1907).

"That the parties intend to be contractually bound appears abundantly clear from the language of the agreements. Consider for example the language in the following agreements, each of which was denied enforcement by the courts: Nebraska Aircraft Corp. v. Varney, 282 Fed. 608 (C.A. 8th, 1922) ; Oakland Motor Car Co. v. Indiana Automobile Co., 201 Fed. 499 (C.A. 7th, 1912); Willhelm Lubrication Co. v. Brattrud, 197 Minn. 626, 268 N.W. 634 (1936).

5 97 Md. 305, 55 Atl. 373 (1903). 
turned on the question of whether the buyer and seller had entered into a legally binding contract. Upon request the seller had sent the buyer prices for 100 tons of tack plate, listing prices for four different gauges. The buyer telegraphed an order for the 100 tons, "specifications to follow." A few days later the seller acknowledged receipt of the order. In holding the agreement unenforceable, the court said:

The price of each gauge was definite; the total quantity was definite, and the times of delivery were definite; but the proportion of each gauge, as well as which of the four would be required, is wholly indefinite and uncertain. As to that element of the alleged contract there was obviously no consensus ad idem.... The test of this lies in considering what would have been the measure of damages in a suit instituted by the vendor against the vendee for a breach of the alleged contract. Would the vendor have been entitled to recover the difference between the contract price and the market price at the whole 100 tons, reckoned on the basis of $\$ 2.80$ per 100 pounds, or on the basis of $\$ 2.72$ per 100 pounds [the variance in price among the four different gauges on the list], or on some other basis founded on an arbitrary apportionment amongst the four different gauges? ... If either court or jury had undertaken such a task, it would have supplied a term of the contract which the parties themselves failed to incorporate, and manifestly such a proceeding would have been unwarranted. ${ }^{6}$

Implicitly relying on the proposition that "that is certain which may be made certain," counsel for the plaintiff contended that it would be a "monstrous perversion of justice" to allow the buyer to escape its obligation to accept and pay for the tack plate by avoiding its duty to specify. The court conceded the merit of this argument but found it inapplicable to the facts. There could be no avoidance of an obligation to specify because no obligation existed. Unfortunately, the court does not discuss the reasons for its conclusion on this issue.

Similar agreements were before many courts during the first forty years of this century. ${ }^{7}$ In many of these cases the rationale of the Wheeling case was adopted. However, a number of factors militate against this result. The very real commercial need for this flexible term is indicated by the frequency of its use. Furthermore, it has been recognized that in stable times there are few instances of completely unjustifiable contract violations or cancellations, but

- Ibid., at 312, 374. "The extreme position taken by the court in [Wilhelm Lubrication Co. v. Brattrud, 197 Minn. 626, 268 N.W. 634 (1936), wherein the court considered an agreement similar to that in Wheeling and used like reasoning] illustrates the tenacity of this aspect of the subjective theory ... generally discarded by the writers, and whittled away by concessions to the necessities of business practice. . ." 37 Col. L. Rev. 309, 310 (1937), noting the Willhelm case, supra.

${ }^{7}$ The cases are collected in Character and Validity of Written Instrument as a Contract for Sale of Goods as Affected by Election or Option in Respect of Subject-Matter, 105 A.L.R. 1100 (1936), and Contract of Sale Which Calls for a Definite Quantity but Leaves the Quality, Grade, or Assortment Optional with One of the Parties as Subject to Objection of Indefiniteness, 106 A.L.R. 1284 (1937). 
that when that stability is threatened a party to a contract may be strongly tempted to violate his word and cancel his contract. ${ }^{8}$ The fact that specifications and apportionment contracts invariably come before the courts in a period of falling prices indicates that buyers are utilizing questionable legalisms to relieve themselves of what has turned out to be a bad bargain. ${ }^{9}$ Recognizing these factors, many courts have upheld and enforced the specification and apportionment contract. ${ }^{10}$

In Burnstein v. Phillips, ${ }^{11}$ an action by the buyer against the seller for failure to deliver, the court had occasion to consider an apportionment contract which did not expressly provide for a power of specification in either party. After holding that the power was in the seller, ${ }^{12}$ the court went on to consider the measure of damages applicable when the power had not been exercised:

A difficulty arises as to the amount of the damages recoverable under this construction of the contract, because it cannot be said with certainty what quantity of each kind of rags should have been delivered, and hence it cannot be said just what plaintiff's loss was, inasmuch as the testimony shows a different rate of loss upon each kind of rags. This should not, however, deprive the plaintiff of all remedy. He is certainly entitled to the least sum which under the evidence he could have lost, i.e., the amount which he is shown to have lost by the failure to deliver two car loads of those kinds of rags respectively upon which the evidence shows there was the least loss. ${ }^{13}$

It may be admitted that, in the sense in which the Wheeling court used the phrase, this result is obtained because the court "supplied a term which the parties themselves failed to incorporate." However, it may be doubted that, as that court thought, "such a proceeding is unwarranted." The rationale be-

${ }^{8}$ Consult generally Business Practice and the Flexibility of Long-Term Contracts, 36 Va. L. Rev. 627 (1950).

${ }^{-}$Consult note 4 supra.

${ }^{10}$ See, for example, the following cases in which the courts have placed special emphasis on the commercial needs and the intent of the parties: William Whitman \& Co. v. Namquit Worsted Co., 206 Fed. 549 (D. R.I., 1913), aff'd 221 Fed. 49 (C.A. 1st, 1915) ; Mebius \& Drescher Co. v. Mills, 150 Cal. 229, 88 Pac. 917 (1907) ; Windsor Mfg. Co. v. Makransky \& Sons, 322 Pa. 466, 186 Atl. 84 (1936).

11 154 Wis. 591, 143 N.W. 679 (1913).

12 This view is rejected in the Uniform Commercial Code, section 2-311(2). "Unless otherwise agreed specifications relating to assortment of the goods are at the buyer's option...." The comment to the section states: "This section rejects the test which mechanically and without regard to usage or the purpose of the option gave the option to the party 'first under a duty to move' and applies instead a commercial interpretation to these circumstances."

${ }^{13} 154$ Wis. 591, 594, 143 N.W. 679, 680 (1913). The holding as to damages is in accord with the rule stated in section 344 of the Restatement of Contracts (1932) pertaining to the measure of damages for the breach of an alternative contract. "An alternative contract is one wherein A promises B some one of two or more alternative performances." Comment a to $\$ 344$. It is clear that the specifications and apportionment contract is one variant of the alternative contract and hence the rule adopted by the court is supported by much authority. Consult authorities cited notes 33 and 36 infra. 
hind the rule stated in Wheeling is that a party should not be subjected to terms to which he has not agreed. But this result does not obtain when the buyer is held for minimum damages under an apportionment contract. $\mathrm{He}$ has agreed to purchase a given amount of merchandise. His power of specification enables him to vary his expenditure under the contract according to the selection he makes, but in no event may he elect to lower his expenditure below a defined limit. He has bound himself to that minimum performance. ${ }^{14}$ Thus, holding him to that minimum performance upon his failure to specify cannot properly be considered as subjecting him to a term to which he has not agreed.

Most courts, however, which have upheld and enforced specification and apportionment contracts, have reasoned not from the buyer's promise of "minimum performance," but rather from his duty to specify. These cases can be divided into three categories, the classification depending upon the means employed by the court to determine that the buyer's power of selection was also a duty.

In the first line of cases the court relied on an express term of the contract in holding that the buyer's failure to specify was a breach of his contractual duties. A number of cases in the early 1920's involving contracts for the sale of sugar are illustrative..$^{15}$ All of the contracts were for the sale of a definite quantity of sugar, "basis $22.50 . " 16$ The contract provided: "Assortment to be furnished to seller by buyer before. ... In event assortment is not furnished promptly, seller reserves the right to ship such grades as it has available at time of shipment." The evidence established that in the sugar trade there existed a standard price differential for fifteen grades based on a basic price for white, fine granulated sugar, in barrels, which in this case was priced at $221 / 2 \%$ per pound. ${ }^{17}$ In American Sugar Refining Co. v. Blake, ${ }^{18}$ the court, in holding that the plaintiff seller need not have tendered to put the buyer in breach, said "the phrase 'assortment to be furnished by buyer,' etc., is no less obligatory in form than [the delivery term] . . . the words 'to be' are used in the imperative sense. . . ."19 It followed that the buyer's failure to specify put him in breach and made tender by the seller unnecessary, the specification being a condition precedent to the seller's duty of performance. ${ }^{20}$

In a second group of cases in which the buyer's power of specification has

' ${ }^{14}$ Compare 10 So. Cal. I. Rev. 504 (1937), noting Willhelm Lubrication Co. v. Brattrud, 197 Minn. 626, 268 N.W. 634 (1936).

${ }^{15}$ In August 1920, there was a sharp drop in the price of sugar which continued until March 1921.

${ }^{10}$ The standard form agreement is reprinted in Franklin Sugar Refining Co. v. Howell, 274 Pa. 190, 195, 118 Atl. 109, 111 (1922).

${ }^{27}$ Tbid.

${ }^{18} 102$ Conn. 194, 128 Atl. 523 (1925).

${ }^{19}$ Ibid., at 201, 525.

${ }^{20}$ Accord: Milliken-Tomlinson Co. v. American Sugar Refining Co., 9 F. $2 d 809$ (C.A. 1st, 1925). 
been held to be a duty, the court did not have an express contractual provision upon which to rely, but admitted parol evidence to show a trade custom or prior course of dealing. In James Talcott, Inc. v.-Marshall Field \& Co. ${ }^{21}$ the defendant had contracted to purchase 125,000 pounds of yarn from among three named grades, but the writing contained no specification provision. The court admitted into evidence the plaintiff's allegation that in the absence of a specification provision it was a trade custom for the buyer to furnish specifications. Relying on this evidence, the court held that the "plaintiff had the right to insist" that the defendant specify. ${ }^{22}$

Finally, there is a third line of cases in which the buyer has been placed under a duty to specify, these involving neither a contractual provision nor a course of dealing or trade custom upon which the court might rely. This was the situation in the comparatively recent case of Dolly Parker Motors v. Stinson ${ }^{23}$ and McIllmoil v. Frazeley Motor Co., ${ }^{24}$ the facts of which are substantially identical. In each the plaintiff buyer sought to recover from the defendant car dealer a sum of money obtained by the latter in the sale of the plaintiff's car. The defense was that the consideration for the defendant's efforts in selling the car was the promise of the plaintiff to purchase a new car and that he had refused to honor this promise. In each case the plaintiff attacked the alleged agreement to purchase a new car on the grounds of indefiniteness, which was said to arise from the failure of the agreement to identify a particular model as the subject of sale. Although the agreements did not purport to obligate the plaintiff to select from among the several models, both courts indicated that the plaintiff's admitted power of specification was also a duty. ${ }^{25}$ These cases can be adequately explained only by a recognition that the circumstances surrounding the formation and performance of an agreement may be such that it is the implied duty of each party to cooperate with the other in every reasonable manner necessary to the other's performance. ${ }^{26}$ Application of this principle to the specifications and

${ }^{2} 15$ N.Y.S. 2d 846 (S. Ct., 1939), aff'd 258 App. Div. 1045, 17 N.Y.S. 2d 1020 (1st Dep't, 1940).

${ }^{22}$ Accord: Cases cited at note 10 supra; and cf. Hinckley v. Pittsburgh Steel Co., 121 U.S. 264 (1887).

${ }^{23} 220$ Ark. 28, 245 S.W. 2 d 820 (1952).

sus 190 Cal. 546, 213 Pac. 971 (1923).

${ }^{25} \mathrm{Cf}$. Posey v. Scales, 55 Ind. 282 (1876), where the agreement provided for the sale of 500 hogs by the plaintiff to the defendant. Defendant had the option of specifying on what day during the two month period the hogs were to be delivered. Upon defendant's failure to exercise the option, plaintiff sold at market price and sought recovery for the difference. The court, in finding for the plaintiff, said: "[The buyers] . . . clearly reserved to themselves the option of indicating at what time, during certain months, the hogs should be delivered to them, and we think it follows that the duty devolved on them of notifying the other parties to the contract when they would receive the hogs." Ibid., at 286.

${ }^{23}$ Consult 3 Corbin, Contracts $\S 561$ (1951); 5 ibid. $\S 1232$ (1951); 6 ibid $\S 1266$ (1951). 
apportionment contract necessarily results in the conclusion that upon failure to specify the buyer is in breach.

\section{II}

The proposed Uniform Commercial Code attempts to provide a definitive solution to the problems raised by the specification and apportionment contract. Consistent with the general policy of the Code to allow for flexibility in commercial transactions, ${ }^{27}$ section $2-311$ provides for the validity of the specification and apportionment contract. ${ }^{28}$ To this extent the Code is in harmony with most of the prior case ${ }^{1 a w^{20}}$ and the writers. ${ }^{30}$ The more interesting questions concern the remedies the Code provides the seller upon the buyer's failure to specify. Subsection (3) of section 2-311 provides that if the selection is "not seasonably exercised," the seller "in addition to all other remedies ... (b) may also either proceed to perform in any reasonable manner or await the time for his own performance and then treat the failure to exercise the option or to cooperate as a breach by failure to deliver or accept the goods."

Presumably, then, upon failure of the buyer to make specifications the seller's first alternative is himself to specify merchandise as conforming to the contract and tender delivery on that basis. ${ }^{31}$ If he should choose not to

27 Uniform Commercial Code $\$ 1-102(2)(\mathrm{b})$.

28 "Section 2-311. Options and Cooperation Respecting Performance. (1) A contract for sale which is otherwise sufficiently definite (subsection (3) of section 2-204) is not made invalid by the fact that the agreement leaves particulars of performance to be specified by one of the parties." The clear purpose of the section is to reverse the result in Wheeling Steel \& Iron Co. v. Evans, 97 Md. 305, 55 Atl. 373 (1903), discussed in text at p. 500. But it is a fair question whether this has been achieved. The section is made dependent upon subsection (3) of section 2-204 which provides that "Even though one or more terms are left open a contract for sale does not fail for indefiniteness if the parties have intended to make a contract and there is a reasonably certain basis for giving an appropriate remedy." While, as has been seen, such a remedy exists, those courts following the Wheeling result have denied this. For example, as Iate as 1936, the Minnesota Supreme Court, citing the Wheeling case, refused to enforce a specifications and apportionment agreement on the grounds that damages could not be assigned on other than an arbitrary basis. Willhelm Lubrication Co. v. Brattrud, 197 Minn. 626, 268 N.W. 634 (1936). While unlikely, it seems not impossible that similar reasoning could be employed even in the face of the Code.

Consult 105 A.L.R., op. cit. supra note \%.

so Consult 1 Williston, Contracts $\$ 42$ (1936); 1 Corbin, Contracts $\$ 100$, at 316 n. 57 (1950).

s1 The New York Law Revision Commission proposed selection of this alternative. The reasons given were that the seller should not be permitted to force upon the buyer unwanted goods; and that the benefit to the seller is illusory since he could not safely risk a later determination on the reasonableness of his performance. The Subcommittee on Article 2 (of the sponsoring organizations) recommended rejection of this proposal, saying that "the provision will not ordinarily permit the seller to 'force' goods on the buyer, but only to fix his damages by resale elsewhere." Report No. 4 of the Subcommittee on Article 2, p. 43 (1955).

Since, as will be seen, the seller retains the privilege of identification if he elects to await 
avail himself of this privilege, he may await the time for his own performance and then bring an action for breach by failure to accept the goods. ${ }^{32}$ Under sections 2-703 and 2-704 the aggrieved seller may "identify to the contract conforming goods not already identified if at the time he learned of the breach they are in his possession or control." Thus, under either alternative, the seller, upon failure by the buyer to make specifications, may himself identify merchandise to the contract. Assuming that the seller has in fact made such identification, he may "resell the goods concerned. ... Where the resale is made in good faith and in a commercially reasonable manner the seller may recover the difference between the resale price and the contract price...."33 This procedure is in conflict with most of the prior case law.

There is some conflict in the case law as to the appropriate measure of damages for breach of the contract by failure to specify, but the vast majority of courts have indicated that justice is best served by allowing recovery on the basis of that selection upon which the seller's profit would be smallest. ${ }^{34}$

the time for his own performance and then hold the buyer for breach, it seems that the seller's alternative of proceeding "to perform in any reasonable manner" would normally be an advantage to the buyer, because it will operate to mitigate damages. The cases usually arise on a falling market. Thus, the longer the period during which the seller is disabled from reselling the merchandise, the larger the damages for which the buyer will be liable.

${ }^{32}$ As the comment to section 2-311 points out, the seller also has available the commercially useful privilege of demanding adequate assurance of performance, as provided in section 2-609. If such assurance is not forthcoming within the time provided the seller may treat the contract as repudiated by the buyer and he is remitted under section 2-610 to the remedies provided in section 2-703.

${ }^{33}$ Section 2-706(1). Where the goods have been identified to the contract, but not resold, the seller may proceed under section 2-708 and recover the "difference between the price current at the time and place for tender and the unpaid contract price ..." ; or may recover the price (section 2-709) if the situation is such that he "is unable after reasonable effort to resell them at a reasonable price or the circumstances reasonably indicate that such effort will be unavailing."

There is a question as to the amount of damages recoverable by a plaintiff who because of unfamiliarity with the provisions of the Code does not identify merchandise to the contract. In Franklin Sugar Refining Co. v. Egerton, 288 Fed. 698 (C.A. 4th, 1923), where the court had occasion to consider a contract identical to those in the sugar cases discussed in text at p. 503, the plaintiff had failed to exercise the power of selection which the contract conferred upon him. The court concluded that "[i]n such case, the measure of damages least onerous to defendant is adopted." Ibid., at 704. While a similar result is possible under the Code, there is no justification for thus penalizing a plaintiff who has not had the benefit of counsel. A sounder result would be reached by permitting the trier of fact to determine a reasonable selection and then to permit recovery under section 2-708. The damages thus provided would be more in accord with the Code policy of administering remedies "to the end that the aggrieved party may be put in as good a position as if the other party had fully performed...." Section 1-106.

${ }^{34}$ E.g., W. J. Holliday \& Co. v. Highland Iron \& Steel Co., 43 Ind. App. 342, 87 N.E. 249 (1909); Franklin Sugar Refining Co. v. Howell, 274 Pa. 190, 118 Atl. 109 (1922). Consult state annotations to Restatement of Contracts $\$ 344$ (1932). 
A few courts have held that damages are to be determined in accordance with the buyer's probable choice. ${ }^{35}$ Still others, in what would seem to provide precedent for the Code's position, have held that upon the buyer's failure to specify the seller has the privilege of doing so. ${ }^{36}$ There has been strong criticism of this latter line of cases. The courts and the writers have assumed that the selection made by the seller would be the one "most onerous" to the buyer, unlike the result reached under the majority rule whereby the damages are based upon the least possible profit. The justification for the majority view is said to be that the seller by entering into the contract has indicated his willingness to be satisfied with the least amount, and the buyer, since he could have thus limited his loss, should be held to no more. ${ }^{37}$

A number of factors, however, cast doubt upon the validity of the reasoning behind the majority view. First, it is doubtful that the seller would specify only that merchandise upon which his profit is greatest. To do so would hardly be consonant with sound business practice. Thus, in the two commercial cases in which the court recognized the seller's privilege of specification (upon the buyer's failure to make the selection), the respective sellers identified equal amounts of the various grades ${ }^{38}$ and the lowest priced of the several alternatives. ${ }^{39}$ Second, while it is true that the seller's contract requires him to be satisfied with the alternative which provides the least profit, it is no less true that he did not contract for the wasteful and time consuming process of litigation. ${ }^{40}$ This factor, while not ordinarily provided for in the assessment of damages, might at least be considered in determining

\footnotetext{
${ }^{35}$ E.g., Black Hardware Co. v. Mt. Vernon-Woodberry Mills, 72 S.W. 2d 303 (Tex. Civ. App., 1934).

${ }^{36}$ E.g.. Alabama Grocery Co. v. Hammond, 285 Fed. 723 (C.A. 5th, 1922), cert. denied 261 U.S. 621 (1923) ; Storm v. Rosenthal, 156 App. Div. 544, 141 N.Y. Supp. 339 (1st Dep't, 1913).

${ }^{37}$ Consult, for example, 5 Williston, Contracts $\$ 1407$ (1937); Measure of Damages for Breach of an Alternative Contract, 7 Md. L. Rev. 161 (1943). Professor Corbin merely states the majority rule, expressing neither approval nor disapproval. 5 Corbin, Contracts $\S 1079$ (1951).

This criticism is undoubtedly aimed at preventing a result similar to that in Jacobson Reimers Co. v. Tozai Co., 42 Cal. App. 178, 183 Pac. 466 (1919). That case involved a maximum-minimum contract wherein the seller had the option of delivering from 200 to 1200 turkeys. Upon the seller's refusal to deliver, the buyer "covered" and brought an action for breach, seeking damages on the basis of 1200 turkeys. Relying on the California Civil Code $\$ 1449$ which provided for transfer of the power of selection, the court allowed recovery for the amount sought.

${ }^{38}$ Alabama Grocery Co. v. Hammond, 285 Fed. 723 (C.A. 5th, 1922), cert. denied 261 U.S. 621 (1923).

${ }^{3}$ Storm v. Rosenthal, 156 App. Div. 544, 141 N.Y. Supp. 339 (1st Dep’t, 1913). Query whether this result would have been reached if the seller's selections would have resulted in a larger recovery?

${ }^{6} \mathrm{It}$ is in recognition of this that the Code includes section 2-609 providing for the right to adequate assurance of performance.
} 
whether the seller's recovery need be limited to the least possible profit he would have made.

Furthermore, it is doubtful that the so-called "most onerous" result could often be reached under the Code. Whether the seller proceeds to perform in any "reasonable manner" or elects to hold the buyer for breach, he is subject to two general provisions of the Code which would control his ability to identify to the contract only that merchandise which will result in the greatest recovery. Section 1-205(3) provides that "The parties to a contract are bound by any course of dealing between them. . . ." Here, the thrust of this provision is that if prior to the agreement in dispute the parties have engaged in a sequence of conduct upon which the seller might base his specifications, he will not be allowed to make selections varying greatly from that basis. ${ }^{41}$

In the absence of a prior course of dealing the "good faith" conduct required by the Code will operate to prevent unreasonable specifications by the seller. ${ }^{42}$ In the case of a merchant "good faith" implies not only "honesty in fact" but includes the observance of reasonable commercial standards. ${ }^{43}$ Prima facie it would appear that good faith is exercised when the selection is within the limits set by the contract, and that hence the so-called "most onerous" result is possible. That that result might be reached by some courts is not to be doubted. It is also true that such a result will sometimes be correct. However, this will not always be so and in such an event a court which makes the attempt can avoid an objectionable result. The avoidance depends upon an analysis of the relationship between the seller's duty of good faith and his privilege of identifying goods to the contract.

The analysis can best be illustrated by posing a hypothetical situation. S, a manufacturer of glass jars, contracts to sell to B, a jobber, 500,000 glass jars: specifications to be provided by $B$ from an attached price list giving prices on three sizes of jars, half gallons, quarts, and pints. Upon B's failure to specify, $\mathrm{S}$ has the power of selecting the apportionment to be identified to the contract. It is obvious that even in the absence of any good faith requirement S's privilege would not extend to a selection of gallon jars, a size not even mentioned in the agreement. This being true, the good faith duty im-

11 The result suggested is analogous to the Code treatment of requirements contracts in section 2-306. Subsection (1) of that section provides that: "A term which measures the quantity by the output of the seller or the requirements of the buyer means such actual output or requirements as may occur in good faith, except that no quantity unreasonably disproportionate to any stated estimate or in the absence of a stated estimate to any normal or otherwise comparable prior output or requirements may be tendered or demanded." (Italics added.)

2Section 1-203. "Every contract within this Act imposes an obligation of good faith in its performance or enforcement."

${ }^{13}$ Section 2-103(1) (b). 
posed upon him by the Code must relate to specifications made within the limits set by the contract. Thus, if S were to specify only half gallon jarsassuming this to be the item upon which his profit is greatest-the question would arise whether the circumstances were such that this could be considered good faith conduct.

The agreement itself provides some evidence that selection of only one size was not contemplated by the parties. It would not be unreasonable for a court to conclude that by naming three sizes the parties implicitly looked toward some apportionment of the three in the total quantity purchased. Hence, in the absence of some showing by the seller to the contrary, a failure to specify in accordance with this expectation ought to be considered prima facie evidence of conduct not in good faith. Even if the seller were able to introduce sufficient evidence to overcome this initial burden the buyer might be in a position to offer evidence that at the time of the agreement an estimated apportionment was discussed or that the circumstances of prior dealing or of the trade were such that it was commercially unreasonable, and hence in bad faith, to select only half gallon jars. ${ }^{44}$

While the problems presented by specifications and apportionment contracts are by no means among those which are the most difficult of solution in the sales field, those courts which have had occasion to consider these contracts have not, on the whole, been capable of applying to them a reasonable commercial interpretation. The Uniform Commercial Code has provided such an interpretation by recognition of the fact that modern commerce requires a high degree of flexibility, as well as the fact that "the essential purpose of a contract between commercial men is actual performance and [that] they do not bargain merely for a promise, or for a promise plus the right to win a law suit. . ...345

"It should be pointed out that a finding that the seller's specifications were not commercially reasonable would not preclude him from all recovery. Good faith performance is a conditioning factor only as to the measure of his recovery. Thus, the damages claimed ought to be disallowed only to the extent that they are based upon reasonable selections.

${ }^{4}$ Comment to section 2-609.

\section{INJURY AS AN ELEMENT IN CRIMINAL FRAUD}

The facts of Nelson v. United States ${ }^{1}$ are simple. Nelson, a retailer of household appliances, had overextended his unsecured line of credit with his supplier. In order to obtain further credit he offered his car as security for all debts outstanding as well as for further loans. In so doing he grossly overvalued his equity in the car, but even so his equity represented more than three times the value of the new loan. Subsequently the car was

I227 F. 2d 21 (App. D.C., 1955). 